\title{
Do Egito a Israel: Passos silenciados e explosivos segundo \\ $O$ som de nossos passos, de Ronit Matalon
}

\section{From Egypt to Israel: Silenced and Explosive Footsteps According to The Sound of Our Footsteps, by Ronit Matalon}

Nancy Rozenchan*

\begin{abstract}
Resumo: A complexidade da vida de imigrantes judeus que foram obrigados a deixar o Egito e se instalaram em Israel há mais de meio século não significou para muitos deles uma possibilidade de ascensão na vida; ao contrário, a antiga posição de acomodamento foi substituída por um rebaixamento inesperado que somente atingiria um desejado equilíbrio na geração seguinte. Neste romance semiautobiográfico, Kol tseadeinu (O som de nossos passos, Am Oved, Tel Aviv, 2008), Ronit Matalon - filha de pais oriundos do Egito -, expõe a própria situação familiar. O verdadeiro ou fictício abonado padrão da família é substituído pelas duras condições de sobrevivência de tripla jornada de trabalho da mãe, ao qual se acresce o quase total abandono por parte do pai jornalista e ativista político marxista, insatisfeito com os moldes que o Israel de então lhes proporcionou na categoria de imigrantes mizrachim, ou seja, judeus provenientes de países árabes. O pai embarca em lutas para denunciar o modelo discriminador do país. A narrativa não linear do romance, conduzida pela filha - alter ego da autora, no papel de testemunha - da tenra idade à idade adulta, se concentra principalmente na mãe, Lucette, e sua atuação de lutadora para se sobrepor ao pequeno mundo a que fora restringida no novo país e à sua condição de esposa semiabandonada. Inconformada, "a mãe" abala a casa - um precário barracão préfabricado -, com suas movimentações. "A casa" - a vida da família - praticamente é sinônimo de "a mãe". O propósito desse texto, além de situar a posição do romance na literatura hebraica contemporânea, é delinear o enfrentamento da mulher que conduz a sua vida e a de seus familiares para a frente, dos seus passos silenciosos, como se lê no primeiro capítulo, aos passos de toda a família, como expostos quase no final do alentado romance.
\end{abstract}

Palavras-chave: Literatura hebraica. Literatura israelense. Ronit Matalon.

\begin{abstract}
The complexity of Jewish immigrants' life who were forced to leave Egypt and settled in Israel more than half a century ago did not mean for many of them a possibility of advancement in life; rather, the old position of accommodation was replaced by an unexpected demotion that would only reach a desired equilibrium in the next generation. In this semi-autobiographical novel, Kol tseadeinu (The Sound of Our Footsteps, Am Oved, Tel Aviv, 2008), Ronit Matalon - daughter of Egyptian parents - exposes the family situation itself. The true or fictitious family standard is replaced by harsh conditions
\end{abstract}

\footnotetext{
*Professora Sênior da FFLCH - USP. Email: <nrozench@usp.br>.
} 
of survival of the mother's triple work day, to which is added the almost total abandonment by the journalist and Marxist political activist father, dissatisfied with the molds that Israel then provided for them in the category of mizrachim immigrants, that is, Jews coming from Arab countries. The father embarks on struggles to denounce the country's discriminating model. The non-linear narrative of the novel, conducted by the daughter - the author's alter ego, in the role of witness - from an early age to adulthood, focuses mainly on the mother, Lucette, and her performance as a fighter to overcome the small world to which she was restricted in the new country and her condition of semi-abandoned wife. Dissatisfied, "the mother" shakes the house - a precarious prefabricated shed - with her movements. "The house" - the family life - is practically synonymous with "the mother". The purpose of this text, in addition to situating the position of the novel in contemporary Hebrew literature, is to outline the confrontation of the woman who leads her and her family's life forward, from her silent steps, as we read in the first chapter, to the steps of the whole family, as exposed towards the end of this lively romance.

Keywords: Hebrew Literature. Israeli Literature. Ronit Matalon.

À medida que a literatura hebraica moderna e contemporânea escrita desde meados do século XIX na Europa e, posteriormente, em Israel, antes e depois da criação do Estado, foi acumulando camadas e matizes, os estudiosos que acompanharam o seu desenvolvimento trataram de definir, classificar e datar os escritos. A cada geração, um dos historiadores dessa literatura se sobressaía nesse mister, e seu registro passava a ser aquele que se tornava mais ou menos oficial. Novos estudos acolhiam esses dados, atualizavam-nos, corrigiam-nos.

Um dos casos de definição hoje pouco mencionada é aquele que se refere à literatura que foi denominada de "literatura da maabará". Quando ela surgiu, a partir da década de 1960, não foi devidamente apreciada. Todavia, foi preciso fazer reparo a isso pois, agora, no século XXI, sessenta anos após o seu surgimento quando, numa segunda geração de autores, ainda brotam escritos que levam a enquadrá-los sob o mencionado título, não se justifica que ela não seja entendida como um dos destacados perfis da literatura hebraica.

Maabará, em hebraico, refere-se a "de passagem, transitório". O termo indica especificamente o tipo de moradia que atendeu a grande parcela da população israelense a partir de 1950: uma moradia transitória para o elevado número de novos habitantes do país que chegaram em grandes massas. Parte desses imigrantes eram "D.P.", segundo a classificação formal inglesa de então de Displaced Persons, pessoas deslocadas, sobreviventes da guerra que não viram alternativa a não ser deixar o seu país de origem devido às consequências da guerra, a perseguições e falta de opções locais. Assim que se deu por findo o Mandato Britânico sobre a Palestina e foi criado o Estado de Israel em 1948, milhares de judeus da Europa, que 
pertenciam a essa categoria, puderam afinal adentrar o país; sobreviventes da guerra, muitos sem família, foi com esta bagagem que tiveram de se adaptar à nova realidade.

Simultaneamente, muitos outros judeus vieram de outras direções, escorraçados dos diversos países árabes onde viveram por séculos. Israel acolheu inicialmente os recémchegados em acampamentos de imigrantes - em hebraico, machanot olim, com tendas de lona e, a seguir, nos acampamentos de transição, as maabarot, espalhados pelo país, onde deveria se iniciar um padrão de vida normal, em que cada família teria a sua moradia. As 127 maabarot instaladas abrigaram cerca de 250 mil pessoas e o seu uso formal perdurou até 1963. Eram constituídas por tendas, choças, carrocerias, barracos ou barracões de lona, de lata, de placas de amianto ou outros materiais ${ }^{1}$. Quando destinadas a duas famílias, a divisão interna da moradia era eventualmente feita apenas de pano, de uma toalha. Algumas foram instaladas na proximidade das cidades; seus habitantes, sempre sujeitos às intempéries, deviam sair à busca de trabalho nas redondezas, em qualquer ofício em que houvesse o que produzir ou construir, no campo ou na cidade. Contudo, com frequência eram saudados pela inexistência de trabalho.

A política oficial foi de espalhar estes acampamentos, tanto quanto possível, por locais distantes do centro do país; deles deveriam brotar posteriormente novas cidades. As maabarot não tinham interação geográfica ou social com as cidades. As condições sanitárias e gerais eram lamentáveis.

A situação do país era então de grande penúria, fato que se acentuava nas maabarot. Embora fossem destinadas a todas as categorias de recém-chegados, a maioria dos moradores era de mizrachim - judeus "orientais" - provenientes de países árabes e/ou muçulmanos, principalmente do Iraque e Marrocos. Em 1951, 75\% dos residentes eram mizrachim; esta porcentagem chegou a $83 \%$ em 1952. Os diversos segmentos de mizrachim sofreram as dificuldades atravessadas pelo país de forma mais marcante do que outros grupos populacionais. Foram o grupo étnico mais marginalizado na sociedade judaica israelense. A par dessas dificuldades, deve-se registrar o complexo enfrentamento com os habitantes veteranos no país, os asquenazes, originários do centro e leste europeu, envolvidos na política e na administração pública, de cultura e padrões sociais diversos e que eram os que ditavam as regras da nação.

As primeiras obras literárias referentes a esse foco começaram a surgir na década de 60 pela mão de autores vindos do Iraque, que já tinham alguma vinculação com as letras em árabe.

\footnotetext{
${ }^{1}$ Receberam diversas denominações em hebraico, algumas delas conforme os materiais de que foram feitos: badon, ohel, asbeston, pachon, tsrif, tsrifon.
} 
O que se escreveu então em árabe no país não amealhou leitores. $\mathrm{O}$ acesso às obras somente começou quando se fez uso do hebraico. As poucas obras literárias da primeira geração refletem a crueza das dificuldades que recaíram sobre todos, os traumas das humilhações pessoais e de grupo pelo rebaixamento de padrões a que se sentiram submetidos, a marginalização, a estigmatização, a vergonha, os empecilhos para se distanciar destes sufocos. Mais do que os sofrimentos particulares dos imigrantes, as histórias vividas nas moradias temporárias são a própria história da construção de Israel.

Em contraste com os que chegaram a Israel como adultos, autores que passaram a infância nas maabarot guardaram primordialmente um sentimento mais positivo para com a vivência daquele período.

As temáticas dessas obras levaram críticos e leitores a incluí-las em categorias diversas, simultâneas ou não, desde a de literatura pós-colonial ou a de literatura de resistência ou outras. É o que se pode verificar no romance feminino Kol tseadeinu (O som dos nossos passos $)^{2}$ da autora israelense Ronit Matalon ${ }^{3}$, filha de judeus provenientes do Egito, que se baseia na dolorosa herança histórica e familiar, uma obra parcialmente autobiográfica em que revisita a história e memórias da família nas décadas 1950-60 em uma maabará em Israel. A narradora foca as memórias primordialmente na figura da mãe.

Dentre os diversos dramas dos judeus egípcios em Israel - bem menos numerosos do que as populações que vieram de outros países árabes, como Iraque ou Marrocos - o que mais os feriu foi o fato de serem considerados semelhantes aos que vinham desses países, muitas vezes com nível sócio-econômico-cultural abaixo do seu. Defrontarem-se com asquenazes, por um lado, e com os demais judeus orientais, por outro, era uma batalha inglória, além de suas forças.

A história da família é transmitida por meio de um enredo não linear com pouco diálogo em 150 capítulos curtos ou curtíssimos, com formas diversas, doze dos quais impressos em itálico, remetendo a temas secundários ou reprodução de textos alheios.

Lucette, a mãe urdidora, seus três filhos e o barracão em que vivem são o centro deste enredo. A Lucette, mencionada sempre como "a mãe", agregam-se Samy, seu filho do breve primeiro casamento, Corinne e Toni, esta citada sempre como "a menina", treze anos mais nova

\footnotetext{
${ }^{2}$ MATALON, Ronit. Kol tseadeinu (O som dos nossos passos). Tel Aviv, Am Oved, 2008, 424 p.. O livro mereceu, em 2009, o Prêmio Bernstein de melhor romance original. A tradução francesa, Le bruit de nos pas, de 2012, de autoria da escritora Rosie Pinhas-Delpuech, mereceu, em 2013, o Prix Alberto-Benveniste.

3 (1959 - 2017). Ficcionista, ensaísta, crítica literária, jornalista, professora de literatura comparada da Universidade de Haifa e de roteiro no Instituto Cinematográfico Sam Spiegel, membro do Fórum de Culturas Mediterrâneas do Instituto Van Leer de Jerusalém.
} 
do que Corinne, único membro da família nascido em Israel e narradora do romance. Em um barracão contíguo, muito menor, vive a avó Ester, a Nonna, mãe de Lucette. Maurice, o marido vagabundeante de Lucette, pai de Toni e Corinne e padrasto de Samy, e o barracão - o casebre da família, que tem personalidade e papel próprios - completam o rol de personagens.

Matalon justapôs a crueza da experiência infantil, daquela identificada apenas como "a menina" (el bint - a filha, como era chamada em árabe) com a perspectiva madura da mãe. $\mathrm{O}$ distanciamento de muitos anos da vida precária no alojamento transitório foi necessário para compor esse relato. "A menina" é narradora testemunha, mas também reprodutora das memórias que ouviu a respeito do período da própria infância e do período egípcio da família e, ainda, relatora e comentarista em primeira pessoa.

No Cairo dos anos 30 a 50 do século XX, de onde era originária, a família se enquadrava na qualificação de "levantina", conceito abordado com frequência por Matalon, fortemente baseado nos escritos da escritora egípcia-israelense Jacqueline Kahanof: os levantinos do Oriente Próximo - judeus e outros - identificavam-se com um universo cultural e de valores europeu mais imaginado do que real, assim como com alguns perfis da vida local com resquícios colonialistas, adequavam-se a eles e deles se beneficiavam. No caso do levantinismo dos judeus, a conceituação aplica-se à camada que era parte da burguesia, uma burguesia judaica. A par dessa faixa social, havia no Egito uma pequena parcela de judeus muito ricos e influentes e, também, uma camada extremamente pobre. Alguns judeus obtiveram aceitação dentro do que era inicialmente um movimento nacionalista egípcio liberal e secular. Como judeus no Egito, compunham um universo particular em que se encontravam membros de diversos outros grupos nacionais e étnicos. $\mathrm{O}$ árabe não era necessariamente a língua principal da burguesia judaica e, sim, o francês ou, em escala menor, outra língua europeia.

A família de Lucette, que fora abonada, tinha perdido o seu status por culpa da vida desregrada do avô mais voltado ao jogo do que aos negócios, uma constante na obra de Matalon, principalmente quando se refere à faixa de chefes de família. Em sequência, a Nonna - a avó fizera a feminina e bela Lucette se casar, em plena adolescência, com um judeu de boas condições financeiras e bem mais idoso, do bairro pobre Harat el Yahud ${ }^{4}$. Aos 16 anos e

\footnotetext{
${ }^{4}$ De acordo com estudos da israelense Liat Maggid Alon, mais de 65\% da comunidade judaica do Egito se considerava parte da burguesia. Geralmente eram famílias com origem em outros países. Os judeus mais pobres viviam no bairro predominantemente judaico de Harat el Yahud. Os da burguesia viviam em bairros diversos. A camada mais jovem deste estrato era falante de francês e partícipe da modernidade. Em contraste, a camada inferior era falante do árabe. Ainda de acordo com ela, a língua falada, o bairro de moradia, a dispersão residencial e casamentos representaram algumas das práticas que permitiram a esta comunidade judaica de imigrantes se reinventarem, a ascenderem como um estrato burguês de intermediários na sociedade egípcia e a pavimentarem o caminho para a modernidade e, através dela, a várias formas de capital. ALON, Liat Maggid. "First Half of the 
grávida, ela fugiu no meio da noite - segundo consta, só de camisola - do marido rude e agressor. Este pai original jamais quis ver o filho. Lucette casou-se então com o amigo do irmão, Maurice, que sempre fora apaixonado por ela, e que assumiu Samy como seu próprio filho. Corinne foi a filha que se seguiu. Nos treze anos entre os nascimentos de Corinne e Toni - "a menina", das várias gravidezes de Lucette resultaram uma morte infantil e vários abortos provocados. Toni foi o resultado da insistência da Nonna para que Lucette a deixasse nascer e da proposta de criá-la. Nonna recorrera a um sonho para convencê-la. Lucette precisava trabalhar duramente para o sustento a fim de suprir o que o marido ausente não proporcionava à família.

Com seu passado egípcio de ativista político marxista e jornalista, Maurice, chocado com a discriminação racista e antidemocrática que seus companheiros judeus sefarditas e orientais sofriam nas mãos do establishment israelense asquenaze, investia contra a doutrina governamental fracassada identificada como o "bengurionismo", baseado na liderança do governante e mais destacado ideólogo da época, David Ben Gurion. Referindo-se ao bengurionismo, o politólogo Carlos Braverman afirma que,

se trató de un protagonismo personalista e ideologizado, pragmático y de dimensiones democráticas muy reducidas. Con su premisa de tierra judía, trabajo judío y autodefensa judía, fundamentó el 'núcleo duro' de su programa político. (BRAVERMAN, 2012, p. 8.)

Um mito que imperou durante várias gerações e muito caro ao bengurionismo foi o de Israel como cadinho de fusão de todas as muitas vertentes que viviam no país. ${ }^{6}$

\footnotetext{
Twentieth Century. The Jewish Bourgeoisie of Egypt in the First Half of the Twentieth Century: Modernity, SocioCultural Practices and Oral Testimonials". In Jama'a: An Interdisciplinary Journal of Middle East Studies Journal. Vol. 24, 2019, p. 7-32. <https://in.bgu.ac.il/humsos/jamaa/DocLib/Pages/jamaa-kd/\%D7\%9C\%D7\%99\%D7\% 90\%D7\%AA\%20\%D7\%9E\%D7\%92\%D7\%99\%D7\%93\%20\%D7\%90\%D7\%9C\%D7\%95\%D7\%9F.pdf?gathSt atIcon=true $>$.

5 "tratou-se de um protagonismo personalista e ideologizado, pragmático e de dimensões democráticas muito reduzidas. Com sua premissa de terra judaica, trabalho judaico e autodefesa judaica, fundamentou o 'núcleo rígido' de seu programa político”. BRAVERMAN, Carlos. "¿Es posible que exista una ciudadanía inclusiva sin una nacionalidad israelí? Una perspectiva politológica". In Revista de Estudios Jurídicos no 12/2012 (Segunda Época) ISSN 1576-124X. Universidad de Jaén (España) p. 8. Disponível em: <https://revistaselectronicas.ujaen.es/index.php/rej/issue/view/79>. Acesso em: 13/10/2020. (Todas as traduções são de minha autoria, N.R.)

${ }^{6}$ É ainda Braverman que destaca que Ben Gurion "No entendió la diferencia entre un crisol étnico que negara el exilio judio y un crisol de culturas transformando el judaísmo, dando lugar a la israelidad." (Não entendeu a diferença entre um crisol étnico que tinha negado o exílio judaico e um crisol de culturas transformando o judaísmo, dando lugar à israelidade). BRAVERMAN, Carlos. "¿Es posible que exista una ciudadanía inclusiva sin una nacionalidad israelí? Una perspectiva politológica". In Revista de Estudios Jurídicos no 12/2012 (Segunda Época) ISSN 1576-124X. Universidad de Jaén (España) p. 8. Disponível em <https://revistaselectronicas.ujaen.es/index.php/rej/issue/view/79>. Acesso em: 13/10/2020.
} 
Maurice funda uma organização de direitos civis e um jornal para exporem o seu antimilitarismo e luta contra a discriminação. Quando essa atividade se mostrou não compensadora, ele se mudou para a Europa para trabalhar como jornalista. Só foi conhecer a filha Toni quando ela estava com cinco anos. Alguns dos capítulos em itálico do romance são trechos de seus escritos (na prática, textos do próprio pai de Matalon, o modelo deste personagem). ${ }^{7}$ Paradoxalmente, enquanto condenava a falta de compaixão do governo para com os diversos perfis da população, ele negligenciava a própria família e menosprezava o fato de Lucette obter o sustento trabalhando como serviçal. Quando, por vezes, retornava à casa, ainda que o casal se amasse, ele era despachado dois ou três dias depois, pois nada de prático resultava da presença incômoda dele. Não bastasse isso, era sobre a mãe que recaíam as consequências das trapaças de que ele se valia para sobreviver.

É de Lucette que a narradora trata e, por extensão, também da família. Guerreira incansável, mas cada vez mais instável, a mãe se esforça freneticamente para levar uma vida decente, muito distante da imagem que mal chegou a construir para si mesma, ainda que no ambiente decadente e um tanto fútil do Egito e orientado por um romantismo calcado na distante cultura francesa sem qualquer pé na cultura local de então em que viveu. A volatilidade física e emocional de Lucette é acompanhada por resultados invariavelmente desafortunados de sua luta implacável para construir algo de seu senso de pertencimento.

Assim como ilustra memoravelmente as paisagens interiores de seus personagens, suas esperanças e sonhos frustrados, Matalon retrata com habilidade as iniquidades sociais do país que rebaixaram a família e inibiram qualquer progresso real que pudesse ser atingido. Lucette trabalha em jornada tripla - como faxineira na casa de um rabino, como faxineira e merendeira em um centro juvenil - e nos afazeres domésticos da lamentável moradia. Viver em Israel era sofrido. Já ao chegar, ela tivera de se submeter às imposições institucionais, como se vê pelo nome que lhe é atribuído ao desembarcar. Como parte da política de israelização, os prenomes dos que chegavam ao país eram hebraizados. Quão simbólico pode ser um nome? Enquanto o nome original - Lucette - pode sugerir algo que ilumine, uma luz, assim que chegou foi-lhe atribuído, por proximidade, o nome de Levana, lua (ou branca), em hebraico. Mas Lucette não o absorve. Levana - lua, recebe sua luz, não a cria. A mãe continua a usar o nome anterior. Por pequeno que fosse o seu facho, ele é que aclarava a orientação da família, mesmo que precariamente.

\footnotetext{
${ }^{7}$ A temática do pai ausente e envolvido na política é abordada em algumas das obras de Matalon. 
Em outro texto, ao se manifestar sobre o hebraico, Matalon declarou: "Writing in Hebrew signifies more than anything else the transformation into Israeliness" (MATALON, $2019)^{8}$. Lucette mal consegue ler ou escrever hebraico e para suprir este entrave serve-se das filhas. Mas não se deixa abalar quando fala. Em resposta à proposta do patrão rabino - um casal asquenaze sem filhos - de adotar sua filha pequena já que ela não tinha meios de criá-la e a menina acabaria perambulando pelas ruas, adotá-la sem que ela perdesse os direitos de mãe, é como Lucette que ela responde enquanto ele se dirige a ela chamando-a de Levana, declarando que não entregará a menina. "O senhor é uma boa pessoa. Mas não costumamos dar os filhos. Haja o que houver, não entregamos as crianças”. (MATALON, 2008, p. 165)

A Nonna, quase cega, é de pouca valia para cuidar da menina. A outra avó, apenas mencionada, é bastante maluca e está afundada em dívidas. Avós cegas ou senis são encontradas igualmente em outras obras de Matalon. São personagens que, com seu alheamento, vivem mais do passado, recusavam-se a sair do Egito físico e sentimental.

Samy, o filho mais velho, devido a uma doença, é cego de um olho. A deficiência pode simbolizar um alheamento parcial à situação em que vive ou justificar o mau ajuste à vida do país. Faz-se de louco para se livrar do exército e empenha-se, em vão, em voltar a servir quando ocorre a Guerra dos Seis Dias, para não se sentir humilhado por permanecer em casa. Trabalha inicialmente como aprendiz de soldador; mais tarde, terá uma oficina de soldagem. A escolha da profissão, não comentada na obra, pode se somar ao seu problema físico e representar a forma como a autora escolheu para expor a visão do país por aqueles imigrantes: o cadinho de fusão das populações não acontece; o que ocorre é mais o resultado de uma soldagem onde provavelmente as junções são visíveis. Os que nasceram fora de Israel vivem o hibridismo identitário. É a história daquela geração. A identidade integral, desvinculada do passado e que permite antever o futuro, será a parcela que caberá aos nativos.

No árduo trabalho diário, Lucette perde toda a feminilidade, pelo que sua mãe, a Nonna, muitas vezes a censura, comparando cruelmente suas próprias mãos brancas, longas e aristocráticas com as mãos inchadas, ásperas e viris de sua filha. Nonna se lembra da "Lucette que ficou no Egito", uma mulher pequena, charmosa e delicada com bochechas rosadas que convidavam as pessoas a apelidarem-na de basboussa, um doce oriental. Em vez disso, o que

\footnotetext{
8 "Escrever em hebraico significa, mais do que qualquer outra coisa, transformar-se em israelidade". MATALON, Ronit, "The Wobbly House - On the presence of Arabic in Hebrew literature". In The Aviv Review of Books, winter 2019. Disponível em: <https://www.tarb.co.il/the-wobbly-house/>. Acesso em: 15/11/2020.
} 
resta dela - enquanto se torna um monstro agressivo e sem palavras que atira objetos perigosos em seus filhos aterrorizados - nada mais é do que uma "imagem da dor". As palavras agradáveis de outrora sumiram de sua boca.

A mãe não se lamenta, o que não significa que não reaja. Ela luta para que o seu casebre seja um lar. Para a menina-narradora, a mãe passou a ser ela própria o casebre, o homem, "ela era a cabana se tornando um homem". (MATALON, 2008, p. 116). A narradora praticamente não vê a mãe como pessoa: "Eles eram em três no barracão, o irmão mais velho, a irmã mais velha e a menina. A mãe não era mais alguém, ela era o barracão em que não havia um homem, e tornou-se o homem”. (MATALON, 2008, p. 116). No nível nacional israelense, às mulheres não foi destinado um papel amplo de resguardo. Assim como aos homens, coube-lhes fazer parte da construção do país, o lar nacional.

Lucette quer um lar. Melhorar o ambiente do casebre, proporcionar mais conforto aos seus era tarefa inglória, sem resultados práticos. Substituir com frequência a toalha de mesa por uma nova, trocar os móveis de lugar para criar como que um novo ambiente, modificar paredes, jogar fora os objetos que lhe pareciam dispensáveis e logo em seguida ir buscá-los de volta não alteram a condição da pequena cozinha sem teto, do banheiro precário. Na maabará prevalece um ambiente de arruaças. Ao menos uma vez por semana, apavorada, temendo principalmente pela menina, ela se defrontava com tumultos quando voltava à noite para casa e dava de encontro com distúrbios em que se aglomeravam "vizinhos, polícia, médico, o vice-diretor do conselho, vizinhos, o merceeiro". (MATALON, 2008, p. 181), O barracão se mostra resistente a todas as tentativas de Lucette de embelezá-lo.

As ações políticas de Maurice não resultam em nenhum eco, e as lides de Lucette na moradia não têm resultado melhor. Cada retorno dela à casa é o prenúncio das suas atitudes diante da situação irremediável. Seus passos mudos antecedem a explosão que ocorrerá assim que entrar em casa.

O que se tem no primeiro capítulo, "O som", trata do som dos passos da mãe, que não são audíveis; o capítulo informa que os passos da mãe não registram nenhum som, mas apenas a ansiedade dos filhos que aguardam a chegada dela depois de seu longo dia de trabalho. O medo silencioso ante a violência da mãe, desencadeada sobre os objetos e habitantes de seu barracão ao encontrar qualquer coisa fora de ordem quando chega em casa à noite, domina o primeiro capítulo. Mais adiante, o retrato da mãe se torna mais suavizado.

\section{O som}


O som de seus passos: não ruído de saltos, não arrastar de pés, não batida de tamancos ou atrito das solas nas pedras da calçada que leva à casa, não. $\mathrm{O}$ sem-som dos passos dela, o pavor crescente em antecipação à sua chegada, sua "entrada", o silêncio absoluto, cheio de conteúdo, medido por uma unidade de tempo de doze minutos, anunciada pela parada do penúltimo ônibus, o ônibus das 23:30 do qual ela descia.

Nossa mãe não pisava, ela deslizava. A grande velocidade, num silêncio total, que segmentava o sossego equilibrado da rua.

O que ela calçava naquela época, que sapatos, ou mais exatamente: com que se municiava para a luta, como, com a ajuda do que. Esse senso de propósito que ela tinha, até o último detalhe, a santidade do propósito, como ela amava o que era útil, necessário. Lembro-me do último par de sapatos dela porque eu os comprei: os primeiros, os primeiros da minha memória. (MATALON, 2008, p. 9)

O impacto da entrada é retardado por uma bonança, uma digressão sobre o tipo de sapato que a mãe gostava de usar, seus detalhes, a cor que ela alterna com frequência - quando são pretos manda tingi-los de marrom e vice-versa, a conversa com o sapateiro, o orgulho de ter pés pequenos, assunto subentendido quando ela comenta que alguém outro tem pés grandes. Todavia, esses comentários em nada reduzem o choque da dor interna dela e do modo como ela se reveste da casa ao entrar; ao contrário, ampliam o clima da expectativa:

Os passos, a caminhada, o retorno, a noite, O retorno à noite, após doze horas de trabalho.

Mas ela não estava à vontade. Sua entrada, o jeito como ela simplesmente irrompia pela porta, morrendo de fome depois de longas horas de fome semcasa, falta-de-casa, de manter as aparências no mundo, que eram a não-casa. O cansaço que a corroía como ácido, também um cansaço do corpo, mas, mais do que isso, o cansaço de manter as aparências, de não-casa.

Ouvíamos as suas entradas, a violência das entradas, conhecíamos cada detalhe na sequência, mas, mesmo assim, nos surpreendíamos novamente. $\mathrm{O}$ pavor era a surpresa. (MATALON, 2008, p. 10-11)

A casa era ela, o olhar que abrangia tudo absorvia o fracasso dos seus empenhos; os pequenos desacertos representam os grandes desacertos da sua vida, desde o casamento precoce, os abortos, a falta do marido, a impossibilidade de um lar completo, verdadeiro, uma casa não-casa, o confronto com uma sociedade que não lhe dá a devida atenção, uma língua que ela não é capaz de dominar, uma posição social inferior numa predominância de uma classe que ela não pode atingir, que quer lhe tomar a filha, os medos da precariedade em tudo, de alagamentos fora e dentro de casa ou a propagação de incêndios. 
Em um olhar de câmara panorâmica, da semiescuridão do corredor, ela absorvia o espaço da casa, digeria, anotava e classificava: uma ligeira mudança na posição do vaso na mesa oval, sapatos deixados no tapete, uma xícara na mesa da sala, alguém estirado no sofá, uma almofada amassada, uma cadeira desalinhada. Mesmo antes de largar a bolsa, ficava com ela no corredor, os olhos estreitando-se, a mandíbula cerrada, coletando evidências, inventando evidências de colapso, de colapso do caos da desintegração de nossa casa. Toda evidência o confirmava. A casa era ela. E qualquer perturbação da ordem correta e apropriada sinalizava que o colapso já havia acontecido ou estava para acontecer. Estava chegando. (MATALON, 2008, p.11)

Do silêncio dos passos ao imponderado rompimento do silêncio, tudo pode levar à reversão: arremesso e quebra de vasos, louça, bater nos filhos com qualquer objeto que estivesse à mão até chegar ao grito: "o grito dela, a entrada, a entrada era o grito". (MATALON, 2008, p. 11)

Os não-sons estranhos dos passos da mãe no primeiro capítulo, o som forte da chuva ocasional inundando a cozinha sem teto, bem como o resto do casebre, as sirenes e as explosões da Guerra dos Seis Dias de 1967, o martelar quase constante das renovações intermináveis que ela realiza, tudo isso é contrastado com momentos de pesado silêncio que dão nos seus nervos durante as observâncias do sábado. Os não-sons, os barulhos, o insuportável silêncio sabático a desgastam. É preciso abrandá-los. Para isso, ela se serve de alguns laivos da cultura anterior que não foram substituídos por novos hábitos. Lucette lê e relê seus livros em francês. A irmã da França traz ou lhe envia pilhas de novelas policiais baratas. Mais do que essas leituras, a menina-narradora guarda na memória o acender e apagar do abajur mais do que uma vez no meio da noite, quando a mãe relê incessantemente La dame aux camélias. Ela não pode recuperar a feminilidade do passado, mas os sentimentos de outras épocas servem para lhe proporcionar alívio. Dois dos capítulos em itálico incluídos no livro são trechos do romance de Dumas.

A alternância dos atos intempestivos se amplia. Lucette pode largar repentinamente uma leitura e romper o silêncio ao ir cavar a areia ao redor do casebre para plantar o jardim de rosas com que sonhava. O cultivo de jardins em condições de subserviência pode ser visto como um ato de libertação e autoafirmação. O que não pode ser obtido no interior da casa pode se concretizar fora dela. Mas, ainda mais do que o barracão, o solo infértil, jamais cultivado, resiste a todas as tentativas de amanho. Apenas o jardineiro palestino contratado a orienta e a encoraja a prosseguir. Sugere que ela permita que as plantas cresçam por si. Paralelamente, Lucette tenta se expressar por meio da pintura, lutando com os diversos tons vermelhos das rosas, vermelhos que ela denomina de bordô. A pintura extrapola as telas. Ela enche a casa de bordô também nos 
móveis. O desespero de não conseguir chegar à perfeição das flores que lhe servem de modelo, leva-a a se livrar das pinturas que, às escondidas, são recolhidas pelo jardineiro.

Com uma breve introdução do personagem palestino, proibido de entrar em Israel para trabalhar quando há situações de conflito, Matalon está indicando a precariedade em que também aquela parcela da população vive. O longo período de ausência do jardineiro leva a mãe o procurá-lo em sua cidade. No dia da visita, a mulher dele tinha dado à luz mais uma menina. Na última cena do romance, - lembrando que ele não é linear - Lucette, surpresa, vê todas as pinturas que descartara expostas na parede da casa miserável. Nas pinturas de flores, folhas e terra, as várias filhas de Mustafá tinham colado terra avermelhada, folhas e flores em cores variadas, algumas já murchando, mas, ainda assim, dando-lhes uma nova oportunidade, assim como a recém-nascida aponta para renovação e continuidade, mesmo nas piores condições. É o último capítulo do livro.

O sonho da casa não se atém aos anseios da mãe, continua na geração seguinte. No septuagésimo aniversário de Lucette, é na casa de Samy, em construção infindável, que se organiza uma festa. Os irmãos não conseguem chegar a um acordo sobre o evento, por si, assunto menos marcante, e quanto a convidar ou não Maurice - assunto primordial, deflagrador de uma cena final surpreendente entre marido e mulher. O que se inicia no capítulo "O quarto vazio (1)" - a descrição da casa de Samy - e o final do mesmo, com a chegada do nem sempre bem-vindo Maurice, é que importam. A ostentação dos detalhes se sobressai: “A casa quase pronta de Samy, construída sob inspiração da Casa Branca, (durante semanas moldaram as colunas como que jônicas: construíram e destruíram, destruíram e construíram)". (MATALON, 2008, 345). Construir um país foi o sonho mirabolante com que a geração imigrante se defrontou. Na sua escala própria, Samy o concretiza à sua moda, com as colunas jônicas, uma das mais escandalosas metáforas do livro ou, ainda, uma paródia.

No dia da festa, Lucette, ao chegar, desconfortável no enorme salão vazio, sequer se dá conta das teatrais colunas, mas é capaz de logo reparar no ângulo da parede mal feito e recomenda que seja corrigido. Para ela, que não pode reparar tudo na família, torná-la completa nos aspectos que não dependiam dela, sempre haveria algo a ser reparado na casa, a representação da família. É contudo, com a chegada do marido, trazido pelo filho, que há lugar para uma reparação familiar: talvez como gesto de reconciliação, com dedos que tremiam devido aos anos de bebida e café, Maurice tira do delicado pacote, que trazia debaixo do braço, um tecido branco fino, semitransparente; em gesto emblemático, desdobra-o e o coloca sobre a cabeça de Lucette, "E ali ele ficou, mole, solto, caindo um pouco sobre a testa e cobrindo os 
seus olhos. Trouxe isso para você do Cairo, Lucette”. (MATALON, 2008, 348). Uma simbólica renovação do casamento, do amor que brotara no Egito.

O tema envoltório da obra, o som dos passos, que tem início com o capítulo "O som", que é o som da mãe, somente se completará em um dos últimos capítulos que leva o título de "O som dos nossos passos" em que, finalmente, a família encontrou a sua unidade.

Até chegar ali, Lucette terá se reconciliado com o que foi possível se reconciliar e enfrentado o que não era passível de modificação. Fugiu do primeiro marido, expulsou de casa o amado Maurice tantas vezes quanto foi possível. Cumpriu uma visita indesejada ao Cairo, encontrou-se com seu antigo apartamento e sua lamentável situação, expressou-se ali no árabe egípcio da infância. Cairo decaíra, assim como a vinculação dela à cidade natal. Lucette viveu para saber que o filho Samy tinha se encontrado com seu meio irmão, cego de um olho como ele, encontro que ela mesma promovera ao conhecer casualmente o filho do primeiro marido em uma das excursões que realizou no Egito; talvez fosse um simulacro para o esperado encontro de Samy com o verdadeiro pai. E essa mulher simples, educada nos códigos estritos da alta sociedade egípcia convencional, ironicamente se tornou uma mulher ferozmente independente graças aos seus modos.

As memórias registradas pela menina, envoltas em fantasias, também podem se tornar visões imaginárias envolvendo descrições oníricas da casa, da família, muito depois da morte de Maurice e Lucette, gerando ainda mais histórias de pequenos momentos compartilhados de espanto ou felicidade, a par da inteireza própria alcançada, legado dos esforços e sofrimentos maternos. As chagallianas cenas do casebre e seus habitantes voadores na série de três capítulos dedicados ao assunto e dispersos pelo livro ("Retrato de Corinne no casebre voador", "Segundo retrato de Corinne no casebre voador" e "Retrato final de Corinne no casebre voador"), com Corinne e seus cabelos (ou seriam cabelos das clientes, uma vez que ela trabalhava como cabeleireira) a pairar e a conduzir o voo é um dos exemplos.

Por sua vez, a série de capítulos “O quarto vazio”, iniciada com o evento do aniversário e colunas da casa e com uma simbólica reconciliação, parte, no segundo de seus capítulos, para observações simbólicas conclusivas da menina. Descrevendo os quartos antigos do casebre que já não existe, a menina devaneia agregando quartos vazios a cada aposento cheio onde dormiam, quartos invisíveis e vazios, densos com o ar diferente de um conhecimento diferente. 
E cada cômodo do casebre tinha uma extensão, não notada a olho nu e vazia, margens vazias para a própria coisa - o quarto - que se tornou a própria coisa, o cômodo vazio que se desdobrava do cômodo cheio, amontoando nele um outro ar de um outro saber, provindo do vazio e não das relações entre as coisas e a fala que tiveram ou não entre si, mas não sufocado pela expectativa, não esperando a revelação de si por si mesmo, ou pelo observador que o redimirá do silêncio silencioso que existe, por exemplo, no vidro polido do espelho. O cômodo vazio teve um tempo diferente, embora sem enredo e desdobramento de enredo, mas não contrário ao humano ou estando acima dele, pelo contrário, cada vez mais dentro dele. (MATALON, 2008, p. 349)

A cena, preenchida pelo imaginário da fantasia e pelo simbolismo do pensamento, sugere colocações que remetem a leituras de temas diversos como, por exemplo, a uma elaboração de Melanie Klein sobre o vazio na cura psicanalítica e na arte, e o papel do imaginário simbólico de superação e reparação de Lacan. Não se trata aqui de resolução dessas questões kleinianas ou lacanianas, mas de entender como o espaço vazio da "menina" parte do espaço cheio - os quartos em que, cheios de vida, dormiam - e que, depois de se adquirir e atingir o conhecimento ali existente, inicialmente desconhecido, desaparece e se torna dispensável. Diversamente do que propõe Klein valendo-se da arte, é a mãe, e a vivência que os filhos tiveram com ela que cumprem e completam o que os filhos necessitaram para crescer e levar a própria vida. A menina descobre o que o quarto vazio tinha ocultado e lhe ensinado da verdade:

que o segredo, escondido dos olhos, mas transparente, era o bom, não o mau, que o segredo era o amor e não a ausência de amor, que o espetáculo fino da graça da felicidade está oculto pelo espetáculo tentador do sofrimento, atraído por ele como uma carruagem transparente de ar como o quarto vazio que contava sua própria história: que o detetive - emissário da justiça e caçador do mau - captura algo no quarto vazio, algo que é oculto e transparente, mas não o criminoso ou o ato criminoso na forma do cadáver, e, sim, o contrário - a graça. (MATALON, 2008, p. 350)

Posto isso, a cena do final, no capítulo "O som de nossos passos" alternando primeira e terceira pessoas, traz mãe e filhos caminhando pela estrada, finalmente unidos em um amor "escandaloso", como definido pela narradora, quando o som dos passos já não lhes importa: talvez estivessem ensurdecidos aos passos devido à chuva, não estão instigados pelo passado ou pelo futuro, mas estão gratos

como pessoas às quais fora concedida a graça do momento; por um momento foram banhados da cabeça aos pés pela limalha dourada do presente, aquecidos pela sua mobília humilde: a chuva, a estrada, a noite, o gato, uma 
calçada não pavimentada, uma frase aleatória dita ou não, um galho torto de lilás persa, o casebre pelo qual passamos sem lhe dar atenção, seguimos adiante.

Tudo tinha sido concluído - não o 'tudo' que é o curso da vida, mas o 'tudo' da consciência da pele tranquila, a pele que realmente vigia através das ruinas da não-supervisão da mente, do coração, das circunstâncias e do destino. (MATALON, 2008, p. 416)

Caminharam no silêncio absoluto e escandaloso de um pacto de amor, com a imagem onírica da chuva caindo até os seus joelhos, não molhando os seus pés ou o asfalto, e formando nesta altura, a meio metro do chão, um fino lago que derramava um brilho sobrenatural, dourado e incomum. A mãe é grata, é dela o apelo “Allah yistor,” Deus nos ajude.

\section{Referências}

ALON, Liat Maggid. First Half of the Twentieth Century. The Jewish Bourgeoisie of Egypt in the First Half of the Twentieth Century: Modernity, Socio-Cultural Practices and Oral Testimonials. In Jama'a: An Interdisciplinary Journal of Middle East Studies Journal. Vol. 24, 2019, p. 7-32. Disponível em: <https://in.bgu.ac.il/humsos/jamaa/DocLib/Pages/jamaakd/\%D7\%9C\%D7\%99\%D7\%90\%D7\%AA\%20\%D7\%9E\%D7\%92\%D7\%99\%D7\%93\%20\% D7\%90\%D7\%9C\%D7\%95\%D7\%9F.pdf?gathStatIcon=true>, acesso em: 13/10/2020.

BRAVERMAN, Carlos. ¿Es posible que exista una ciudadanía inclusiva sin una nacionalidad israelí? Una perspectiva politológica. In Revista de Estudios Jurídicos nº 12/2012 (Segunda Época) ISSN 1576-124X. Universidad de Jaén (España) p. 8. Disponível em: <https://revistaselectronicas.ujaen.es/index.php/rej/issue/view/79>, acesso em: 13/10/2020.

MATALON, Ronit, The Wobbly House - On the presence of Arabic in Hebrew literature. In The Aviv Review of Books, winter 2019. Disponível em: <https://www.tarb.co.il/the-wobblyhouse>, acesso em: 15/11/2020.

MATALON, Ronit. Kol tseadeinu (O som dos nossos passos). Tel Aviv, Am Oved, 2008. 